University of Nebraska - Lincoln

DigitalCommons@University of Nebraska - Lincoln

Faculty Publications: Department of Entomology

January 1998

\title{
Arthropods on Pine Foliage in Urban Landscapes
}

Mary Ellen Dix

USDA Forest Service

Frederick P. Baxendale

University of Nebraska-Lincoln, fbaxendale1@unl.edu

Follow this and additional works at: https://digitalcommons.unl.edu/entomologyfacpub

Part of the Entomology Commons

Dix, Mary Ellen and Baxendale, Frederick P., "Arthropods on Pine Foliage in Urban Landscapes" (1998).

Faculty Publications: Department of Entomology. 136.

https://digitalcommons.unl.edu/entomologyfacpub/136

This Article is brought to you for free and open access by the Entomology, Department of at DigitalCommons@University of Nebraska - Lincoln. It has been accepted for inclusion in Faculty Publications: Department of Entomology by an authorized administrator of DigitalCommons@University of Nebraska - Lincoln. 


\title{
Arthropods on Pine Foliage in Urban Landscapes ${ }^{1}$
}

\author{
Mary Ellen Dix ${ }^{2}$ and Frederick Baxendale ${ }^{3}$ \\ USDA Forest Service, Rocky Mountain Forest and Range Experiment Station, National Agroforestry \\ Center, Lincoln, Nebraska 68583-0822 U.S.A.
}

J. Entomol. Sci. 33(1): 113-120 (January 1998)

Key Words Urban landscapes, windbreaks, turfgrass, biological control, predators, parasites.

Urban landscapes are dense heterogenous matrices composed of turf broken up by tree patches or corridors (Forman and Godron, 1986, Landscape ecology. John Wiley, NY). Trees and their associated understory vegetation in the urban landscape provide food and protective habitat for many arthropods and their natural enemies and increase biological and spatial diversity (Andow, 1991, Annu. Rev. Entomol. 36:561-586). Pest management strategies that enhance the abundance of natural predator populations are alternatives to chemical pesticides. The goal of this research was to obtain essential baseline information on pine trees in turf landscapes by identifying common families or classes of arthropod predators and phytophagous prey, determining their relative abundance, and describing their seasonal occurrence.

In 1991, we selected five tree-turf landscapes in Lincoln (Lancaster Co.), NE and one in Saunders Co., NE with ponderosa (Pinus ponderosa Laws.) or Austrian (Pinus nigra Arnold) pines growing adjacent to tall fescue (Festuca arundinacea Schreb.) or bromegrass (Bromus sp.). Two sites were adjacent to golf course fairways (GC1, $\mathrm{GC2}$ ), two sites were located in city parks (P1, P2), and two sites were bromegrass meadows in suburban (WB1) and rural (WB2) landscapes.

Turfgrass management levels at the study sites ranged from high with regular fertilization and mowing golf course sites (GC1, GC2) to minimal with little fertilization and infrequent mowing suburban and rural landscapes (WB1, WB2). Maintenance at the city parks (P1, P2) was intermediate, consisting of occasional fertilization and mowing. Insecticides were not used at any of the sites. Trees at all the sites were at least 20 years old. Tree height ranged from 5 to $10 \mathrm{~m}$ and varied within and among sites. Tree height at GC1, WB1, and P1 averaged $9.9 \pm 0.36 \mathrm{~m}(n=5), 7.9 \pm 0.50 \mathrm{~m}$ $(n=5)$, and $8.1 \pm 0.16 \mathrm{~m}(\mathrm{n}=6)$, (over $7 \mathrm{~m})$, respectively. Tree height at GC2, WB2, and P2 averaged $6.0 \pm 0.49 \mathrm{~m}(\mathrm{n}=5), 5.1 \pm 0.17 \mathrm{~m}(\mathrm{n}=5)$, and $5.7 \pm 0.24 \mathrm{~m}(\mathrm{n}=$ 5) (less than $7 \mathrm{~m}$ ), respectively. The distance between adjacent trees at all sites ranged from 3 to $5 \mathrm{~m}$.

Branch shakes were used to sample trees for foliage-inhabiting arthropods. In

\footnotetext{
${ }^{1}$ Received 05 July 1996, accepted for publication 26 June 1997.

${ }^{2}$ Research Entomologist.

${ }^{3}$ Extension Entomologist, Department of Entomology, University of Nebraska, Lincoln, Nebraska 68583-0816.
} 
1991 and 1992, two and four branches/tree, respectively, on each tree were sampled at each site (1991: 10 branches total, 1992: 20 branches total). In 1992, two branches (1991: 1 branch) were sampled at the mid-crown (approximately 3 to $5 \mathrm{~m}$ high) and two branches (1991: 1 branch) were sampled at approximately $1.5 \mathrm{~m}$. The terminal 50 $\mathrm{cm}$ of each branch was shaken vigorously into a net for approximately $10 \mathrm{~s}$ (Dix and Baxendale, 1995, Proc. 1994 Soc. Am. For. Natl. Conv. 471-472).

Sites were sampled for foliage-inhabiting arthropods from May through October with weekly sampling in 1991 and monthly sampling in 1992. Samples were returned to the laboratory and stored in $70 \%$ ethyl alcohol for later identification and counting Collected arthropods were categorized as predators or prey. Arthropods were identified by J. Kalish and R. Roselle of the University of Nebraska Plant \& Pest Diagnostic Clinic.

Arthropod collection data for each site were summarized by year and month. Predator and prey counts per branch within a site were summed and prey/predator ratios calculated. Contingency tables (Bonferroni-adjusted) compared total catches of predators between years $(\alpha=0.05)$ (SAS Institute, 1992, SAS Technical Report P-229. Cary, NC). Monthly predator and prey catches within a site were analyzed using the PROC GLM. Tukey's studentized range tests $(\alpha=0.1)$ compared abundance among months. Individual trees were considered the basic sampling unit for calculation of statistical error at each site. Data from sites with similar maintenance (i.e., $\mathrm{GC}_{1}$ and $\mathrm{GC} 2$ ) was not pooled because the sites differed from each other in tree height, understory vegetation and other landscape characteristics. An $\alpha=0.1$ was used because family abundance varied considerably among sites and dates.

Spiders, ants (Hymenoptera: Formicidae), lady beetles (Coleoptera: Coccinellidae), and minute pirate bugs, Orius tristicolor (White), comprised over $90 \%$ of the predators on the branches in 1991 and 1992 (Table 1). Lacewings (Neuroptera), harvestmen (Arachnida: Opiliones), syrphids (Diptera: Syrphidae), and rove beetles (Coleoptera: Staphylinidae) comprised the remainder. A few parasitic wasps (braconids and ichneumonids) were collected on the branches.

A larger percentage of spiders, lady beetles, ants, and rove beetles were captured in 1991 than in $1992(P<0.05)$ (Table 1, Fig. 1). In addition, a larger percentage of harvestmen, minute pirate bugs, and other predators were captured in $1992(P<$ 0.05 ), especially at P2 and WB2 during May (Fig. 1). In 1992, approximately $24 \%$ of the total predators captured at WB2 were minute pirate bugs. In 1991 and 1992, the total predators averaged 1.0 and 3.8 per tree, respectively, or approximately 0.25 and 0.5 predators per $50 \mathrm{~cm}$ of branch, respectively. In both years, predator numbers were similar at all sites except WB2 in 1992, where over 8 predators were collected per tree (Fig. 2).

Aphids (Homoptera: Aphididae) were the most abundant phytophagous prey on the branches (>99\%) (Table 1). Flea beetles (Coleoptera: Chrysomelidae), leafhoppers (Homoptera: Cicadellidae), grasshoppers (Orthoptera), and stink bugs (Heteroptera: Pentatomidae) accounted for the remaining prey. In 1991 and 1992, total prey averaged 8.2 and 38.7 per 4 branches (Fig. 2), respectively, or approximately 2.1 and 9.7 prey per $50 \mathrm{~cm}$ of branch, respectively. Aphids (total prey) were most abundant on trees at GC2, P2, and P1 in 1991 and at WB2, P2, and P1 in 1992 (Fig. 2).

Prey/predator ratios varied with site and year. Ratios were highest for P1 and $\mathrm{GC} 2$ in 1991 and for P1 and P2 in 1992 suggesting that predators may have been less available for reducing prey on trees at these sites.

Total prey (aphids) abundance on trees varied during the year at the 6 sites (Figs. 
Table 1. Total predators and prey collected on pine branches in turf landscapes in Lancaster CO. and Saunders Co., NE

\begin{tabular}{|c|c|c|c|c|}
\hline \multirow[b]{2}{*}{ Predators } & \multicolumn{2}{|r|}{1991} & \multicolumn{2}{|r|}{1992} \\
\hline & Number & Percent of total & Number & Percent of total \\
\hline Spiders & 1057 & 74.8 & 503 & 56.6 \\
\hline Ants & 142 & 10.0 & 60 & 6.7 \\
\hline Lady beetles & 108 & 7.6 & 33 & 3.7 \\
\hline Lacewings & 25 & 1.8 & 17 & 1.9 \\
\hline Minute pirate bugs & 39 & 2.8 & 218 & 24.5 \\
\hline Big-eyed bugs & 4 & 0.3 & 0 & 0.0 \\
\hline Rove beetles & 21 & 1.5 & 0 & 0.0 \\
\hline Harvestmen & 12 & 0.8 & 38 & 4.3 \\
\hline Syrphids* & 4 & 0.3 & - & - \\
\hline Other predators ${ }^{\star *}$ & 2 & 0.1 & 20 & 2.2 \\
\hline Total predators ${ }^{\star \star}$ & 1414 & 100.0 & 889 & 99.9 \\
\hline \multicolumn{5}{|l|}{ Prey } \\
\hline Aphids & 14407 & 99.7 & 6957 & 99.4 \\
\hline Flea beetles & 0 & 0.0 & 23 & 0.3 \\
\hline Leafhoppers & 0 & 0.0 & 10 & 0.1 \\
\hline Grasshoppers & 4 & 0.02 & 2 & 0.03 \\
\hline Stink bugs & 37 & 0.25 & 4 & 0.06 \\
\hline Total prey ${ }^{\star * *}$ & 14448 & 99.97 & 6996 & 99.89 \\
\hline
\end{tabular}

* Syrphids were not counted in 1992.

** Other predators $=$ Damsel flies and carabids.

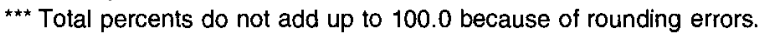

3 , 4). In both years, prey abundance usually was significantly higher (1991: $F=11.48$, $\mathrm{df}=213, P<0.01 ; 1992: F=8.50, \mathrm{df}=114, P<0.01)$ in September or October. In 1991 , predator abundance at GC1 $(F=3.44, \mathrm{df}=213, P<0.01)$ and $\mathrm{P} 1(F=8.50$, df $=205, P<0.01)$ varied significantly during the year. Spiders $(G C 1, P 1)$, lady beetles (P1, GC2, P2, WB2), ants (P1), minute pirate bugs (GC2, P2), and other predators (GC1) were higher at specified sites in September or October (Fig. 3).

In 1992, total predator abundance varied significantly with month for GC1 ( $F=$ 2.24, df $=114, P<0.06)$, WB1 $(F=2.88, \mathrm{df}=114, P<0.03), \mathrm{GC2}(F=6.96, \mathrm{df}=112$, $P<0.01), \mathrm{P} 2(F=5.02, \mathrm{df}=115, P<0.01)$, and WB2 $(F=19.01, \mathrm{df}=116, P<0.01)$ (Fig. 4). At five sites, reductions in prey abundance on the trees immediately preceded increases in prey. Total predator abundance was significantly higher at 3 sites 

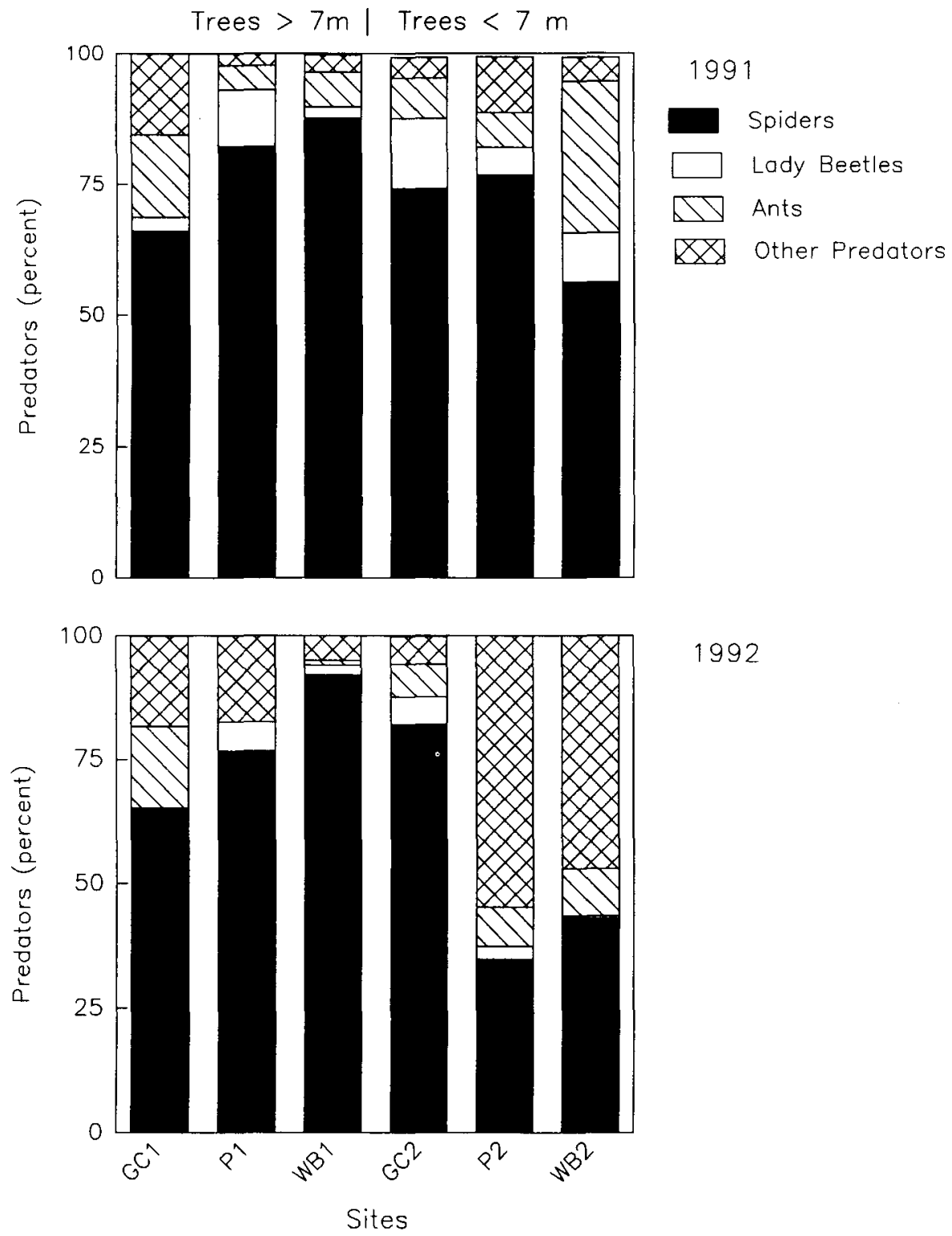

Fig. 1. 1991 and 1992 relative predator abundance on $50 \mathrm{~cm}$ long pine branches from turf landscapes in Lancaster Co. and Saunders Co., NE. 
Trees $>7 \mathrm{~m} \mid$ Trees $<7 \mathrm{~m}$

Trees $>7 \mathrm{~m} \mid$ Trees $<7 \mathrm{~m}$

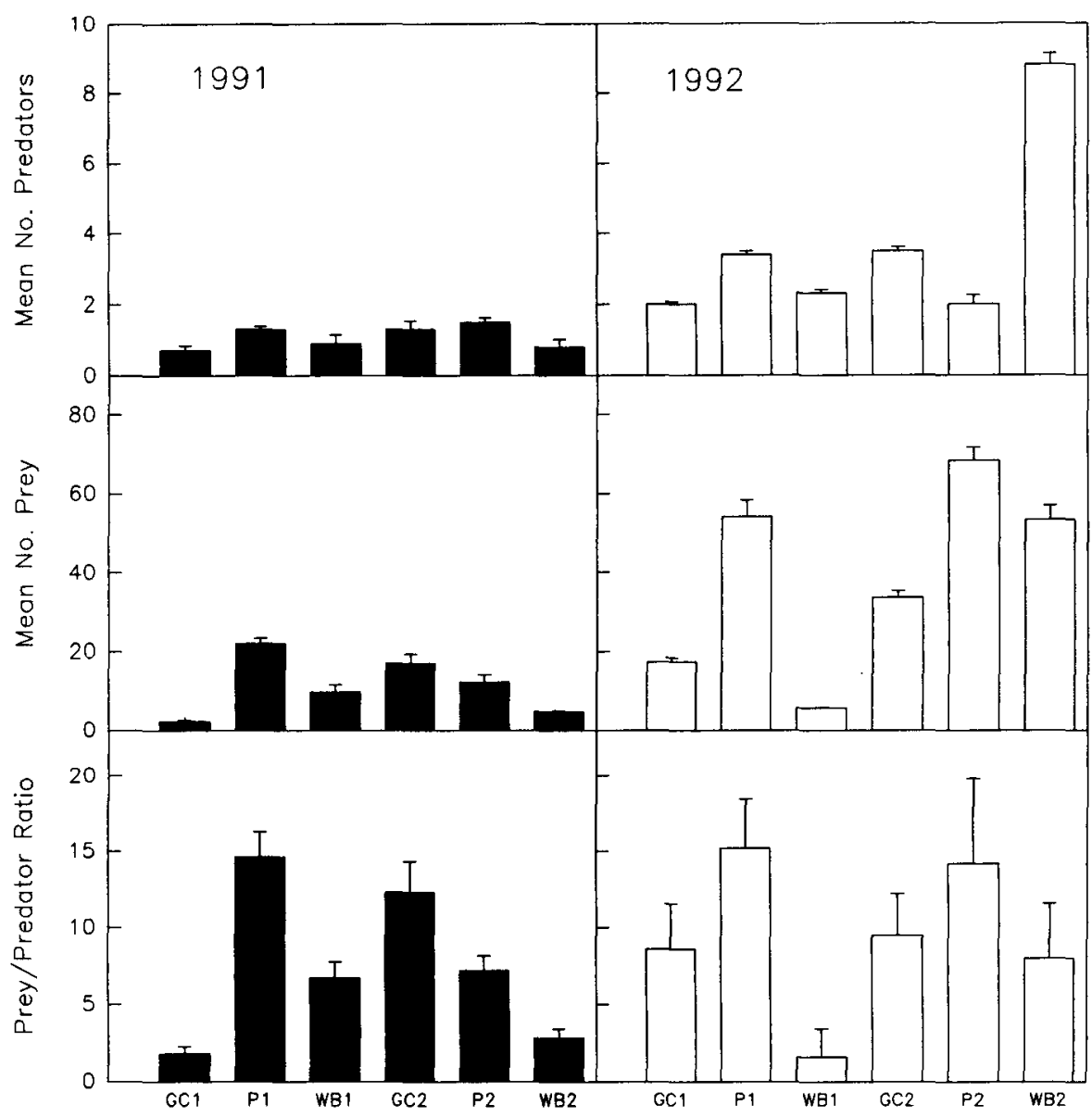

Sites

Fig. 2. 1991 and 1992 mean total predator, prey (aphids) and prey/predator ratios on a $50 \mathrm{~cm}$ long pine branches from turf landscapes in Lancaster Co. and Saunders Co., NE.

(GC2, P2, WB2) in August or September (Fig. 3, 4). Spider abundance peaked at three sites (GC1, GC2, WB2) in either August or September (Fig. 4). In general, predator groups because they are omnivores, tended to compensate for each other with abundance of one predator group increasing as abundance of another predator group decreased.

Natural enemies usually maintain pest populations below epidemic levels and their cumulative effects on a pest can be greater than their individual impacts (Potter, 1992, 


\section{Branches}

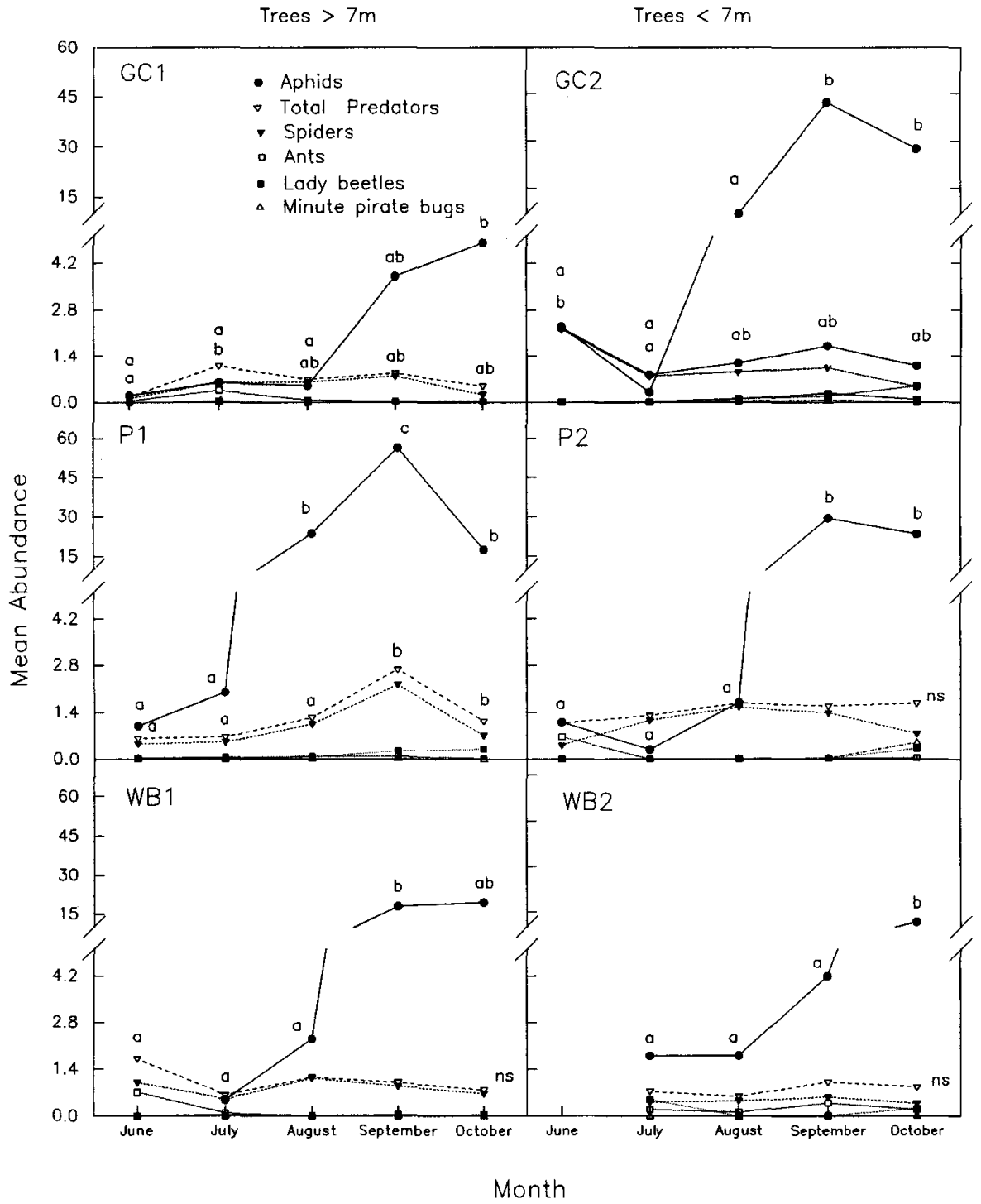

Fig. 3. 1991 mean monthly predator and aphid (prey) abundance on $50 \mathrm{~cm}$ long pine branches from turf landscapes in Lancaster Co. and Saunders Co., NE. Monthly aphid means (higher letters) and monthly total predator means (lower letters) with different letters are significantly different according to Tukey's studentized range test $(P<0.01$ for aphids, $P<0.10$ for total predators). 
Trees $>7 \mathrm{~m}$

Trees $<7 \mathrm{~m}$

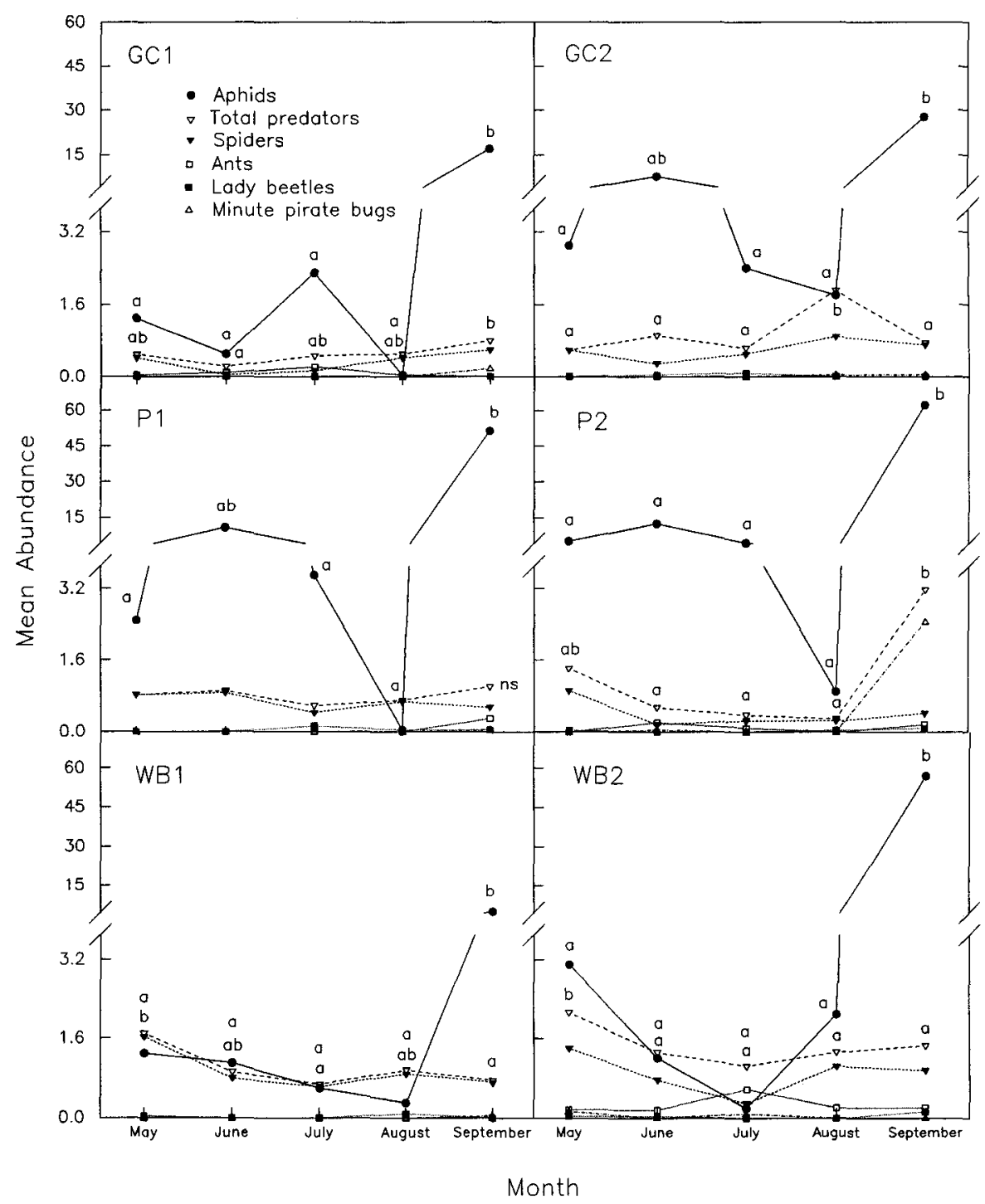

Fig. 4. 1992 mean monthly predator and aphid (prey) abundance on a $50 \mathrm{~cm}$ pine branches from turf landscapes in Lancaster Co. and Saunders Co., NE. Monthly aphid means (higher letters) and monthly total predator means (lower letters) with different letters are significantly different according to Tukey's studentized range test $(P<0.01$ for aphids, $P<0.10$ for total predators). 
USGA Section Record: November-December 1992. 6-10). In our study, the lack of severe tree insect outbreaks at any site studied suggested that biotic factors played a role in restricting prey abundance. Spiders seem to be the primary predator on the pines followed by ants. These predators maintained aphids and other possible important herbivorous pests below outbreak levels especially early in the year. However, climatic and other environmental variables also may have a major impact on prey abundance on the trees.

Foliage-inhabiting predator and prey populations varied extensively over time and site in these urban landscapes. These results provide baseline information on common arthropod predators and prey on pines in urban turf landscape. This information is crucial to the development of pest management strategies that enhance natural enemy populations.

The authors wish to thank L. Gustafson, M. Gustafson, E. Pfeifer, T. Weinhold, R. Roselle, M.-S. Kim, T. Hovland, J. Kalish and J. Irwin for their technical assistance, R. King and $L$. Young for their statistical review of the manuscript, and N. Klopfenstein, M. Harrell, S. Danielson, R. Cunninghan, J. Zhang, E. Hart and R. Wright for their technical reviews of the manuscript. Research was supported in part by the University of Nebraska Agriculture Experiment Station Project NEB-17-062. This paper 11561 of the journal series of the Agricultural Research Division, University of NebraskaLincoln. Voucher specimens are deposited in the USDA Forest Service Rocky Mountain Forest and Range Experiment Station's Great Plains Tree Insect Collection located at the National Agroforestry Center on the University of Nebraska campus. 